\title{
Cost and Profit Efficiency of Bangladeshi Commercial Banks: A Stochastic Frontier Approach
}

\author{
Bellal Hossain Raju Md. \\ Department of Finance, University of Dhaka, Dhaka, Bangladesh
}

Email address:

mbhraju@gmail.com

To cite this article:

Bellal Hossain Raju Md. Cost and Profit Efficiency of Bangladeshi Commercial Banks: A Stochastic Frontier Approach. International Journal of Economic Behavior and Organization. Vol. 5, No. 6, 2017, pp. 131-142. doi: 10.11648/j.jjebo.20170506.13

Received: May 9, 2017; Accepted: May 25, 2017; Published: December 19, 2017

\begin{abstract}
This paper assesses the cost and profit efficiency levels of banks consist of conventional, Islamic Shariah based and state-owned commercial banks in Bangladesh over the period of 2011 to 2015. Basic accounting ratios and stochastic cost and profit approaches originated by stochastic frontier analysis have been used in this study. From the results of accountingbased ratios used in this study, conventional private commercial banks are more efficient compared to Islamic Shariah based private commercial banks and state-owned commercial banks in the both cases of cost and profit. According to the stochastic cost frontier approach, the commercial banks in Bangladesh are not found considerable cost inefficient. The cost efficiency level of 35 commercial banks in Bangladesh is 91.4 percent. The results of this study indicate that traditional private commercial banks are more cost efficient compared to Islamic Shariah based and state-owned commercial banks. From the results of stochastic profit efficiency frontier, the conventional private commercial banks have the higher values of alternative profit efficiency levels than the state-owned and Islamic Shariah based commercial banks. It can also be drawn that around one-fourth of profits of banks are lost because of inefficiency over the period covered by this study.
\end{abstract}

Keywords: Cost Efficiency, Profit Efficiency, Accounting Ratios, Stochastic Cost Frontier Approach, Stochastic Profit Frontier Approach, Commercial Banks, Bangladesh

\section{Introduction}

Banking industry leads the financial sector of Bangladesh. The vulnerability of the financial sector is largely made by the dominance of the banking sector; on the other side, the contribution of the industry in wealth allocation, as well as mobilization and economic progress, is highlighted by this dominance. The function of the banking sector in speeding up growth is largely depended on the soundness and profundity of the industry. The banking sector has journeyed a time where the sector has tested several ups and downs in Bangladesh. Transformations have been carried out in an attempt to improve upon the structural constraints of the sector.

Banking system always plays a significant role in the economic development of any country. The main components of the banking system are commercial banks. Commercial banks have to be competent else; they will create instabilities and blockades in the process of the expansion of any economy. Technological advancements and globalization modify and intensify the situation for the banks to maintain market shares in order to survive and remain competitive. Competitions created by the foreign banks as well as by the local banks themselves create larger pressure. Bangladeshi commercial banks are not free from this pressure also. Consequently, commercial banks need to be not only profitable but also be efficient, since commercial banks exposed to robust competition both domestically and internationally.

The banks need to be effective for the appropriate mobilization of the economic resources. A drop in spreads between lending and deposit rates is the primary advantage to enhance efficiency, and this will possibly stimulate both larger financing demand for industrial investment and more prominent arrangement of economic savings by the banking mechanism (Ikhide) [1].

Securing efficacy in the banking sector, which makes stronger the efficiency of implemented economic policies in the large scale, inducing continuous development, financial growth, and well-being (Irsova) [2]. Contemporary 
tendencies in the market expansion of the banking sector comprise the rising interest for banking amenities and financial services on the larger global level, the collective effect of the quicker technological progress, a diminution in the guidance of the industry and interference along with a growing rivalry on the marketplace.

In this study for measuring the efficiency of commercial banks in Bangladesh, stochastic frontier analysis is used; which is an output-oriented parametric approach. The study also used accounting ratios, which are a crude measure. The study mainly focused on the technical efficiency of banks.

\subsection{Scope of the Study}

The nature of this focus is exceptionally extensive. The efficiency measurement of the banking industry of Bangladesh requires in-depth study of the whole banking sector. The experiential study of financial data, as well as information, is all about conducting efficiency measurement through managerial efficiency, cost efficiency, liquidity efficiency, profit efficiency, debt and leverage efficiency, market efficiency, and technical efficiency.

This paper endeavored to concentrate only on the certain financial attainments based on the selected specific factors. Besides, estimation and computation of efficiency demand more other attentions. Subsequently, financial performance measurement through the accounting ratios and the stochastic frontier analysis covers most of the area of the efficiency measurement that directs towards conducting of such a study and will certainly be giving an effective output.

\subsection{Objectives of the Study}

This paper aims mainly to explore the cost and profit efficiency intensities of Bangladeshi commercial banks through a comparison of the practice of basic accounting ratios and the stochastic frontier analysis: cost and profit frontier approach.

To attain the broad objective successive specific objectives have been emerged,

(1) To make a comparative analysis among the commercial banks in Bangladesh regarding their efficiency.

(2) To construct some notions on how effectively and efficiently resources can be utilized in the banking industry for the sake of economic development.

\section{Literature Review}

Parametric and non-parametric approaches both have been used in the earlier works on banking studies. The superiority of one method over another is a matter of discord among the scholars. Accounting ratios, still a crude extent is very convenient to use. Conversely, the interpretation of the outputs provided by this method must be handled with care and caution.

\subsection{Accounting-Based Ratios}

The previous study in the banking sector was mostly dealt with assessing the mean productivity, cost comparison and some indices used for that reason (Farrell) [3]. Afterward, scholars were likely to use market share for proxy efficiency with the hypotheses that, the banks with larger market shares might be anticipated to attain higher proceeds due to having a lower cost per unit compared to the banks with smaller market shares (Smirlock) [4] and (Evanoff \& Fortier) [5]. Additionally, sustaining the existing price levels and scope or decreasing the position of prices and growing could be a way of maximizing profits for the banks with smaller cost structures. Further efficient firms gained through the accreditation of a positive association between market structures and firms' profits.

Banking researchers use accounting ratios as a crude measure to gauge banks performance and efficiency. Annual reports of each bank provide these ratios deliberately for that reason they are convenient to use. Despite its contrary concerns, the basic financial parameters of operating performance such as operating expenses divided by the shareholders' equity or total assets or income, have also been used to contrast efficiencies. It can be seen through the studies of bank efficiency before and after mergers conducted by Rhoades [6], Srinivisan \& Wall [7], and Cornett \& Tehranian [8].

Still, some limitations make it challenging and require extra caution while using accounting ratios. Berger, Hunter, and Timme [9] stated that financial ratios do not limit for input prices or a mix of product that is why they are considered as deceptive indicators of efficiency. The second problem is that the usage of cost to asset ratio presumes that in the production all assets are equally costly and undertaking business in different locations has the same cost. Lastly, Xefficiency gains and scale and scope efficiency gains cannot be differentiated by the simple use of accounting ratios.

\subsection{Stochastic Frontier Approach}

In 1977, Aigner, Lovell \& Schmidt, [10] and Meeusen \& Van den Broeck [11] constructed the econometric frontier approach, which is popularly known as the stochastic frontier approach. The stochastic frontier approach stipulates an operational structure of the production, cost or the profit frontier as well as it permits for random error. Under this method, the stochastic frontier approach adjusts the basic cost or profit function to let inefficiencies contained within the error term. The projected standard cost function is presumed to illustrate the frontier when any absent of efficiency is apprehended in the term that is an error in nature. This function is a four-sided structure of the projected frontier. Calculated inefficiencies that are influenced by this assumption to be not associated with the regressors and direct derivation of any measure or product mix economies from these explanatory variables (Ferrier \& Lovell) [12].

To differentiate the ineptitudes from the unorganized elements of the error term is another required assumption in the stochastic frontier approach. Separate banks in pretty high or low-cost points that are placed by the short-term break and quantify error from explanatory variables that are 
left out, and misinterpreted terms are the random components. Separation of these two random elements is done by presuming that the asymmetric half-normal distribution is the source of inefficiencies and the symmetric normal distribution is the cause of random errors. Breakdown of residuals of individuals in inefficiency terms or random variant is complicated and not possible most of the times. It also implies that, a complexity of measuring technical efficiency by the use of observations.

For the reckoning of the cost function of the profitoriented banks of Malaysia for the period from 1991 to 1997 and the reconstruction of banks influenced by this frontier, Okuda, Hashimoto \& Murakami [13] employed stochastic frontier approach. The research paid attention to the economies of scale, not to the economies of scope and based on the findings proposed by the study. The local commercial banks of Malaysia were involved in ineffective long-term investments. Some of the scholars used both the stochastic frontier approach and data frontier analysis. Yildirim \& Philippatos [14] applied both of the frontier methods to determine the cost and profit efficiencies of different banking institutions covering twelve European countries. Their study got the results of 77 percent by stochastic frontier approach and 72 percent by data frontier approach in the average cost function position.

\subsection{Technical Efficiency and Inefficiency}

Theoretically, a bank is said to be efficient when it generates a maximum potential amount of output possible with the given level of inputs available. This efficiency directs efficiency of a production frontier. Therefore, the position held by the production frontier denotes a combination of technically efficient input and output. Besides, when a bank generates an amount of output under the production frontier, the bank is said to be inefficient. It indicates a production of output less than the maximum achievable amount of output.

The real difficulty arises from the assessing of production function. To address the issue, Farrell [3], Aigner and Chau [15] and Richmond [24] made several endeavors for the formulation of the production frontier. They focused and employed linear and quadratic programming approaches to get a form of production frontier in their studies. There were some obvious limitations. One of the critical shortcomings was that the effect of random shocks caused by the external variable was not integrated with the production frontier.

Later, to solve the difficulty or limitations faced by the production function, Aigner, Lovell \& Schmidt [10] and Meesun \& Broeck [11] separately developed and estimated a stochastic production frontier where a clear incorporation of inefficiency parts and error terms was made. Further, Battese \& Coelli [16] used the stochastic production frontier including cross-sectional data of selected firms. Their study defined the technical efficiency in a broader sense. The considered the technical efficiency as the proportionate of a firm's average perceived production, its recognized effect, to the way of interrelated average production, assuming that the effect of the firm was null.

\section{The Banking Sector of Bangladesh}

\subsection{An Overview of the Banking Industry}

After the birth of Bangladesh, six commercial banks and two specialized banks, which were nationalized and stateowned respectively along with two foreign banks, made the banking industry of Bangladesh. Establishment of private banks in the early eighty (1980) extended the banking sector of Bangladesh remarkably. At present, there are mainly two types of banks in Bangladesh.

Scheduled Banks are established and operated by the Bank Company Act, 1991 (amended up to 2013) whereas NonScheduled Banks are formed with specific and unique objective and controlled by the acts legislated for the attainment of those aims. Non-Scheduled Banks do not have the authority to conduct all the activities performed by a Scheduled Bank.

At present, 57 scheduled banks carry out their operations in Bangladesh. They are conducting their operations under the direct supervision and regulation of Bangladesh Bank (the central bank of Bangladesh). Bangladesh Bank has the legal authority to act through Bangladesh Bank Order, 1972 and Bank Company Act, 1991.

Table 1. Types of Banks in Bangladesh.

\begin{tabular}{lll}
\hline \multicolumn{2}{l}{ Scheduled Banks } & $\mathbf{5 7}$ \\
\hline 1. & State-Owned Commercial Banks (SOCBs) & 6 \\
2. $\quad$ Specialized Banks (SDBs) & 2 \\
3. $\quad$ Private Commercial Banks (PCBs) & 40 \\
& Conventional PCBs & 32 \\
$\quad$ Islamic Shariah based PCBs & 8 \\
4. $\quad$ Foreign Commercial Banks (FCBs) & 9 \\
\hline Non-Scheduled Banks & $\mathbf{4}$ \\
\hline
\end{tabular}

Source: Bangladesh Bank [17]

From the Table A1. List of Commercial Banks of Bangladesh included in the appendices, all 57 banks with full name, year of establishment, type of bank and listing status in the stock exchange can be obtained to get the complete synopsis of the scheduled banks of Bangladesh.

\subsection{Structure of Banking Sector}

In the year 2015, 27.5 percent of all the total assets of commercial banks was detained by the state-owned commercial banks, which was almost equal to the previous year. An increase of 1.2 percent from 63.3 percent in 2014 to 64.5 percent in 2015 was taken place in the private commercial banks' total assets.

Besides, foreign commercial banks experienced a weakening of 0.3 percent in 2015 by holding 5.2 percent of the total assets. The portion of total assets of the specialized banks was 3.7 percent in 2014, which became 2.8 percent in 2015 due to the conversion of consideration as one specialized bank into state-owned commercial bank.

The Scheduled banks' total deposits was BDT 7,928.6 billion 
in 2015 through a rise from BDT 6,965.1 billion in 2014 means 13.8 percent general growth. The state-owned commercial banks held a trivial increase from 28 percent to 28.4 percent in 2015 in total deposits. In 2015, the total deposits of private commercial banks became BDT 5,110.4 billion in volume equivalent to 64.5 percent of total deposits of all banks from BDT 4,449.4 billion or 63.9 percent in the previous year.
The foreign commercial banks experienced a little increase of BDT 10.8 billion in 2015 form 2014 in its total deposits although its share of total deposits was 4.3 percent in 2015 , which was 4.7 percent in 2014. The specialized banks' deposits in 2015 was 2.9 percent that was lesser than 2014 holding an amount of BDT 226.6 billion in 2015 compared to BDT 237.6 billion in 2014.

Table 2. Banking System's Structure in Bangladesh.

\begin{tabular}{|c|c|c|c|c|c|c|c|c|c|c|c|c|}
\hline \multirow{3}{*}{$\begin{array}{l}\text { Bank's } \\
\text { Type }\end{array}$} & \multicolumn{6}{|l|}{2014} & \multicolumn{6}{|l|}{2015} \\
\hline & \multicolumn{2}{|l|}{ Number } & \multicolumn{2}{|c|}{ Total Assets } & \multicolumn{2}{|l|}{ Deposits } & \multicolumn{2}{|c|}{ Number } & \multicolumn{2}{|c|}{ Total Assets } & \multicolumn{2}{|l|}{ Deposits } \\
\hline & Banks & Branches & Amount & $\%$ & Amount & $\%$ & Banks & Branches & Amount & $\%$ & Amount & $\%$ \\
\hline SOCBs & 5 & 3,553 & $2,517.1$ & 27.5 & $1,952.1$ & 28.0 & 6 & 3,690 & $2,839.6$ & 27.5 & $2,254.8$ & 28.4 \\
\hline SDBs & 3 & 1,500 & 333.8 & 3.7 & 237.6 & 3.4 & 2 & 1,406 & 291.3 & 2.8 & 226.6 & 2.9 \\
\hline PCBs & 39 & 3,917 & $5,787.2$ & 63.3 & $4,449.4$ & 63.9 & 39 & 4,226 & $6,652.9$ & 64.5 & $5,110.4$ & 64.5 \\
\hline FCBs & 9 & 70 & 505.0 & 5.5 & 326.0 & 4.7 & 9 & 75 & 530.8 & 5.2 & 336.8 & 4.3 \\
\hline Total & 56 & 9,040 & $9,143.1$ & 100 & $6,965.1$ & 100 & 56 & 9,397 & $10,314.6$ & 100 & $7,928.6$ & 100 \\
\hline
\end{tabular}

Note: All the amounts are stated in Billion BDT

Source: Bangladesh Bank's Annual Report, 2015-2016 [18]

\section{Data and Methodology}

\subsection{Sources and Selection of Data}

The sample banks in this study consist of 6 state-owned commercial banks and 29 private commercial banks. Among the private commercial banks, 22 are conventional private commercial banks and 7 are Islamic Shariah based private commercial banks established and operated in Bangladesh. The list of all scheduled banks in Bangladesh including the banks used as the sample in this study is shown in Table A1. The study covers a duration of five years from 2011 to 2015 . Required data was taken from the Profit and Loss Account, Balance Sheet and Cash Flow Statement included in the Annual Report of the respective banks covering the time horizon from 2011 to 2015.

All in all, 175 observations were studied in this paper. Observations with negative values were ignored because of the ln-linear measurement in the assessed model. This study will follow the intermediation method. Intermediation approach considers banks as financial mediators. As per intermediation approach, banks accumulate deposits, labor, and capital in order to make credits and investments. This study considers the financial worth of loans and investments as output standards. As inputs, this study considers deposits, labor, and capital where total cost includes operating and fiscal expenses.

\subsection{Accounting Ratios}

Three key accounting ratios consist of operating asset ratio, operating income ratio, and operating equity ratio are used in this paper. A detailed comparison is conducted for each ratio. For observing the efficiency of banks through both interest margin ratios and operating cost ratios, the lower the proportion (margin or cost), the higher the efficiency and vice versa. On the other hand, in the case of profit ratios, the higher the profit ratio, the more efficient the bank is. To observe the values of accounting ratios of the individual bank for the period from 2011 to 2015 at a glance,
Table A2 is attached in the appendices.

\subsection{A Stochastic Cost Frontier}

Cost efficiency examines the banks' economic output compare to the outstandingly performed banks, which make same performance under the same extrinsic circumstances. Under the stochastic frontier approach, the stochastic cost function works through a cost equation that correlates cost of a bank to factors causing those costs. Levels of output affected by the input prices are the widely accepted basis for the stochastic cost function approach.

The cost equation developed by the stochastic cost function incorporates a combined error structure, which differentiates irregular cost deviations from the absent of cost efficiency. From a simple sense, a stochastic cost function portrays the connection or relation between the cost accompanying the sizes of input and output variables with the inefficiency and error that incurs randomly.

The cost equation is as follow as:

$$
\mathrm{C}=\mathrm{f}(\mathrm{y}, \mathrm{w}, \mathrm{z})+\mathrm{u}+\mathrm{v}
$$

In this equation (1), $\mathrm{C}$ computes the total expenses (costs) of bank containing operating plus financial expenses. $y$ and $w$ act as vectors, $\mathrm{y}$ for outputs and $\mathrm{w}$ for input costs. $\mathrm{z}$ symbolizes constant bank parameters in amounts. $u$ represents inefficiency term, which grabs the gap between the cost efficiency level for a given levels of output and input costs and the real cost level. Finally, $\mathrm{v}$ is the irregular (random) error phrase.

A natural logarithm form of the cost efficiency equation can be expressed as follows;

$$
\ln \mathrm{TC}=\mathrm{f}(\mathrm{y}, \mathrm{w}, \mathrm{z})+\ln \mathrm{u}_{\mathrm{t}}+\ln \mathrm{v}_{\mathrm{t}}
$$

In this equation (2), $f$ designates structure of a function. When a specific cost function is estimated, later the relationship between the least cost may also be referred as minimum cost $\left(\mathrm{C}_{\min }\right)$ required to generate $\mathrm{i}$ bank's output and 
the real $\operatorname{cost}\left(\mathrm{C}_{\mathrm{i}}\right)$ quantifies the cost efficiency of that bank.

$$
\operatorname{COSTEFF}_{\mathrm{i}}=\frac{c_{\min }}{c_{i}}=\frac{\exp [f(y, w, z)] \times \exp \left(\ln u_{\min }\right)}{\exp [f(y, w, z)] \times \exp \left(\ln u_{\mathrm{i}}\right)}=\frac{u_{\min }}{u_{i}}
$$

In this equation (3), $u_{\min }$ denotes the lowest $u_{i}$ over the entire banks included in this study. For more clarification of the outputs of this function an example can be narrated as, a bank with 0.90 cost efficiency score means that 90 percent of the bank's real costs could have been incurred by that bank.

\subsection{A Stochastic Profit Frontier}

In addition, profit efficiency examines in what handy way a bank tries to accomplish the maximal attainable profit as an outstandingly performed banks on the frontier in the certain quantities of inputs and prices of output and additional extrinsic parameters. This study uses the alternative profit function to sidestep the complexities of having the measurement of output prices that are not included in this study.

The alternative profit function uses the exact group of external variables used in the equation (1) of the cost function where the profit is the dependent variable instead of the total cost.

The profit function can be inferred as follows:

$$
P=f(y, w, z)+u+v
$$

In this equation (4), $\mathrm{P}$ computes the profit of a bank containing interest and fee based income minus total cost availed in the cost equation.

A natural logarithm form of the profit efficiency equation can be expressed as follows;

$$
\ln \mathrm{P}=\mathrm{f}(\mathrm{y}, \mathrm{w}, \mathrm{z})+\ln \mathrm{u}_{\mathrm{t}}-\ln \mathrm{v}_{\mathrm{t}}
$$

The proportionate relation between a bank's true profit and the maximal attainable profit that is accomplishable by the best practice bank quantifies the profit efficiency of that bank.

$$
\operatorname{PROEFF}_{\mathrm{i}}=\frac{P_{i}}{P_{\max }}=\frac{\exp [f(y, w, z)] \times \exp \left(\ln u_{\mathrm{i}}\right)}{\exp [f(y, w, z)] \times \exp \left(\ln u_{\max }\right)}
$$

In this equation (6), $u_{\max }$ denotes the highest $u_{i}$ over the entire banks included in this study. For more clarification of the outputs of this function an example can be narrated as, a bank with 0.95 profit efficiency score means that 5 percent of the bank's possible profits is given up due to the administrative ineptness while picking ideal output numbers and input expenses.

The related variables used in this paper are given below and the descriptive statistics of the values of used variables are presented in Table A3.

The maximum likelihood parameter estimation constructed by Battese \& Coelli [19] is used at the same time to deduce the cost and profit models. FRONTIER Version 4.1, a Disk Operating System (DOS) based computer package developed by Coelli (1995), has been operated to get the maximum likelihood estimations of variables in computing technical inefficiencies.

The computer package is able to afford cross sectional and panel data. It can accommodate cost and production function. It can also serve half-normal and truncated normal distributions and consider time-varying and invariant efficiency. The package can count functions having a logged or original dependent variable in units

\section{Analysis and Findings}

\subsection{Accounting Ratios}

Table A5 displays the mean value of accounting ratios of the individual bank selected in this study. Operating ratios dictate average interest margin are to some extent higher for Islamic Shariah based private commercial banks having Interest Margin to Assets (IMA): $2.86 \%$, Interest Margin to Income (IMI): $69.85 \%$, and Interest Margin to Equity (IME): $38.25 \%$ relative to conventional private commercial banks (IMA: 2.14\%, IMI: $41.49 \%$, IME: $25.87 \%$ ), state-owned commercial banks are not comparable due to negative values in several years in that case. An almost same pattern of results is observed in the operating asset, income, and equity ratios. On the other hand, operating ratios also indicates operating cost on average where Islamic Shariah based private commercial banks (Operating Cost to Assets (OCA): 1.68\%, Operating Cost to Income (OCI): $41.71 \%$, Operating Cost to Equity (OCE): $22.70 \%$ ) have lower values compared to the conventional private commercial banks (OCA: 2.68\%, OCI: 53.04\%, OCE: $32.62 \%$ ), state-owned commercial banks are found between the other two type of commercial banks (OCA: $1.79 \%$, OCI: $49.33 \%$, OCE: $25.78 \%$ ). These ratios indicate a vague determination of cost efficiency of commercial banks in Bangladesh. By observing operating cost ratios, Islamic Shariah based commercial banks are found more cost efficient than the conventional and state-owned commercial banks. The different case happens in the profit ratios, conventional private commercial banks (Pre-Tax Profit to Assets: 2.06\%, Pre-Tax Profit to Income: $40.76 \%$, Pre-Tax Profit to Equity: 24.17\%) have the higher values than the other type of commercial banks in Bangladesh. That directs that the conventional private commercial banks be more profit efficient compared to the Islamic Shariah based commercial banks.

In the case of the individual conventional commercial bank, SOUTHEASTB has the lowest operating costs followed by STANDBANKL and DHAKABANK. Besides, it is found that ONEBANKLTD has the highest profit ratios followed by EBL and DUTCHBANG, where MTB experienced the lowest profit efficiency followed by PREMIERBANK and TRUSTBANK. In case Islamic Shariah based commercial bank, SHAHJABANK is found with the lowest interest margin followed by EXIMBANK. ALARABANK and ISLAMIBANK experienced the highest profit efficiency. State-owned commercial banks are not comparable due to negative values in several years in that case also. As a whole, the overall values obtained by accounting ratios point out conventional private commercial banks are more efficient compared to Islamic Shariah based private commercial banks in the both cases of cost and profit. 
Conversely, accounting ratios are used as a crude measure to estimate banks performance, and efficiency that required particular attention while interpreting (De Young) [20]. Besides, greater operating costs lead to more significant expenses to back wider-spread branches, technological advancement and excellent delivery of service to clients.

\subsection{Stochastic Cost Frontier}

The cost frontier approach produced the outputs, which are included in Table A6. Based on the outputs using the cost function in this study, 22 conventional private commercial banks performed in a cost efficiency level of 93.5 percent on an average. This result indicates that the banks wasted around 6.5 percent of its resources while providing services to its customers during the study period. Among the 22 banks, UTTARABANK has the highest average cost efficiency score of 98 percent followed by NBL (97.3 percent) and SOUTHEASTB (96.4 percent). The lowest average cost efficiency score belongs to PUBALIBANK (84.9 percent) followed by EBL (87.9 percent) and BANKASIA (90.9 percent). With more than 95 percent of mean cost efficiency level BRACBANK (96.4 percent), and PREMIERBANK (96.5 percent) are in a savvy position.

On the other hand, Islamic Shariah based private commercial banks experienced an average cost efficiency level of 91.1 percent. This efficiency level means that 8.9 percent of the wealth of Islamic private commercial banks is squandered while performing banking activities. From the 8 Shariah based banks, FIRSTSBANK scored 97.6 percent in mean cost efficiency score followed by EXIMBANK ( 94.2 percent) and ISLAMIBANK (94.1 percent). SHAHJABANK has the lowest average cost efficiency level of 86.7 percent followed by ICBIBANK (89.1 percent) and SIBL (87.3 percent).

Again, the mean cost efficiency level of 6 state-owned commercial banks is 83.4 percent. That means 16.6 percent of their resources are destroyed while conducting banking operations. The greatest mean cost efficiency level of these types of commercial banks is 93.8 percent held by JANATABANK followed by BASICBANK (93.2 percent). The least score of average cost efficiency is produced by BDBL (52 percent) followed by RUPALIBANK (84.6 percent) over the study period.

Totally, the stochastic cost frontier has been produced a cost efficiency level of all commercial banks in Bangladesh included in this study is 91.4 percent. There is a wastage of 8.6 percent of resources held by the commercial banks of Bangladesh over the period covered by this study.

The outcomes in percent of cost efficiency score generated by this study are relatively higher than the results estimated by the studies of banking industry of Bangladesh conducted earlier such as Samad [21], varies in an extent of 15 percent to 25 percent. For all type of commercial banks in Bangladesh, the cost efficiency score has improved over the study period.

\subsection{Stochastic Profit Frontier}

The outputs produced by the profit efficiency projection are included in Table A7. Several earlier studies in estimating efficiency, the cost efficiency estimates are found higher than the projections of alternative profit efficiency levels (Berger and Mester, 1997 on banks of USA). By profit efficiency measures, the alternative profit efficiency score of traditional private commercial banks is 79.1 percent on average higher than the Islamic Shariah based commercial banks having 73.1 percent. Based on the scores obtained by commercial banks in Bangladesh, a conclusion can be drawn that around one-fourth of profits of banks are disappeared because of inefficiency over the period covered by this study.

Among the 22 conventional based banks, UCB has the highest average profit efficiency estimate of 92 percent followed by EBL (91.8 percent) and ONEBANKL (91.0 percent). The lowest average profit efficiency score belongs to MTB (52.6 percent) followed by NCCBANK (62.4 percent) and PREMIERBANK (64.2 percent). Having above 90 percent of mean profit efficiency level SOUTHEASTB (90.2 percent), and PUBALIBANK (90.1 percent) are in a strong position.

Besides, Islamic Shariah based private commercial banks made an average profit efficiency level of 73.1 percent. This efficiency level means that 26.9 percent of the benefits of Islamic private commercial banks are lost while performing banking activities. From the 8 Shariah based banks, ISLAMIBANK scored 87.6 percent in mean profit efficiency estimate followed by ALARABANK (86.9 percent) and SIBL (83.2 percent). FIRSTSBANK has the lowest average profit efficiency level of 38.7 percent followed by SHAHJABANK (61.4 percent). ICBIBANK is excluded from the estimations because of the bank has been facing negative profit and equity over the study period.

From the period of 2011 to 2015, most of the commercial banks in Bangladesh have lessened their profit efficiency. The cause behind the decreasing pattern in the profit efficiency is the increasing expenses incurred by the banks to face intense industry competitions and to give superior services to customers.

\section{Suggestions}

The employees of bank require having an extensive point of view. This requirement is because they strive for cutting expenses strictly to have a greater efficiency as well as profitability. Necessary steps are essential to be taken for the financial institutions, which are operating to persist and still flourishing in this competitive world (FIS) [22].

There are five proven ways to enhance efficiency of bank substantially with no additional risk and consistency in serving clients. The ways include, recognize the key branches and improve the delivery channels properly, start business process improvements by associating enhanced level of technologies, integrate sales resources with market opportunities, assess strategic sourcing prospects, and assess the most effective outsourcing options.

Based on the analysis and results of this study, few proposals can be given to improving efficiency level of 
several banks.

(1) Operating costs should be allocated to different heads by an improved set of activities including avoiding over employment, controlling other overheads as much as possible to ensure the best use of costs.

(2) Advancing credit and advance or investment operations to ensure given resources are fruitfully and efficiently utilized with the minimum cost. Maintaining quality growth in investment in government and other financial securities so that maximum possible earnings can be obtained.

(3) A consistent and optimum proportion should be maintained while meeting loan and advance or investment demand and liquidity requirement. Stateowned commercial banks should be more cautious in selecting and evaluating potential credit clients and maintain additional capital to face undesirable events.

(4) Return on assets should exceed 1 percent through the equal contribution by all banks operating in the banking industry of Bangladesh. To attract increased number of potential real investors and make the existing shareholders content, return on equity should cross the boundary of 10 percent where each and every commercial bank should perform spontaneously.

\section{Conclusion}

In the 21st century, the financial structure of Bangladesh has experienced a remarkable transformation. The impact of global integration and hi-tech development force the banking industry to operate in a distinctive way. As a result, banks are giving emphasis to obtain the maximum profits and incur the minimum costs. Thus, this study scrutinizes the cost and profit efficiency of commercial banks in Bangladesh through basic accounting ratios, and cost and profit functions developed by the stochastic frontier approach.

This study suggests based on the outputs that the overall values obtained by accounting ratios point out conventional private commercial banks are more efficient compared to Islamic Shariah based private commercial banks and stateowned commercial banks in the both cases of cost and profit. Probably, the reasons of that are the greater number of branches and wider spread network of services captured by the conventional private commercial banks than the Islamic Shariah based private commercial banks. The different scenery appears for the state-owned commercial banks; they underperform due to the managerial inefficiency and fraudulent activities conducted by related stakeholders.

The stochastic frontier approach develops cost and alternative profit functions to estimate efficiency level. In the maximum earlier works on the efficiency of commercial banks, it is found that the frontier of regular bank significantly differs from the outstandingly performed bank frontier. The commercial banks in Bangladesh are not found considerable cost inefficient. The cost efficiency level of 35 commercial banks in Bangladesh is 91.4 percent. There is a wastage of 8.6 percent of resources held by the commercial banks of Bangladesh over the period covered by this study. The results of this study indicate that traditional private commercial banks are more cost efficient compared to Islamic Shariah based and state-owned commercial banks (93.5 percent against 91.1 percent and 83.6 percent).

The alternative profit efficiency estimates are found somewhat lower than the projections of cost efficiency levels. From the results of this study, the conventional private commercial banks have the higher values of alternative profit efficiency levels than the state-owned and Islamic Shariah based commercial banks (79.1 percent against 73.1 percent). It can also be drawn that around one-fourth of profits of banks are disappeared because of inefficiency over the period covered by this study.

The outputs or measures of this study should be deduced very carefully as several earlier studies deviate significantly due to diverse measurement approaches. Distinctive estimation methods should be used in future to generate comparable results.

\section{Appendices}

Table A1. List of Scheduled Banks of Bangladesh.

\begin{tabular}{|c|c|c|c|c|}
\hline Name & Short Name & Est. & DSE & $\mathbf{Y} / \mathbf{N}$ \\
\hline \multicolumn{5}{|l|}{ Private Commercial Banks - Conventional } \\
\hline AB Bank Limited & ABBANK & 1982 & $\mathrm{~L}$ & $\mathrm{Y}$ \\
\hline Bangladesh Commerce Bank Limited & BCBL & 1998 & & $\mathrm{~N}$ \\
\hline Bank Asia Limited & BANKASIA & 1999 & $\mathrm{~L}$ & $\mathrm{Y}$ \\
\hline BRAC Bank Limited & BRACBANK & 2001 & $\mathrm{~L}$ & $\mathrm{Y}$ \\
\hline Dhaka Bank Limited & DHAKABANK & 1995 & $\mathrm{~L}$ & $\mathrm{Y}$ \\
\hline Dutch-Bangla Bank Limited & DUTCHBANG & 1995 & $\mathrm{~L}$ & $\mathrm{Y}$ \\
\hline IFIC Bank Limited & IFIC & 1976 & $\mathrm{~L}$ & $\mathrm{Y}$ \\
\hline Jamuna Bank Limited & JAMUNABANK & 2001 & $\mathrm{~L}$ & $\mathrm{Y}$ \\
\hline Meghna Bank Limited & MEGHNA & 2013 & & $\mathrm{~N}$ \\
\hline Mercantile Bank Limited & MERCANBANK & 1999 & $\mathrm{~L}$ & $\mathrm{Y}$ \\
\hline Midland Bank Limited & MIDLANDBANK & 2013 & & $\mathrm{~N}$ \\
\hline Modhumoti Bank Limited & MODHUMOTI & 2013 & & $\mathrm{~N}$ \\
\hline Mutual Trust Bank Limited & MTB & 1999 & $\mathrm{~L}$ & $\mathrm{Y}$ \\
\hline
\end{tabular}




\begin{tabular}{|c|c|c|c|c|}
\hline Name & Short Name & Est. & DSE & $\mathbf{Y} / \mathbf{N}$ \\
\hline NRB Bank Limited & NRBBANK & 2013 & & $\mathrm{~N}$ \\
\hline NRB Commercial Bank Limited & NRBCOMBANK & 2013 & & $\mathrm{~N}$ \\
\hline NRB Global Bank Limited & NRBGLOBANK & 2013 & & $\mathrm{~N}$ \\
\hline One Bank Limited & ONEBANKLTD & 1999 & $\mathrm{~L}$ & $\mathrm{Y}$ \\
\hline Premier Bank Limited & PREMIERBANK & 1999 & $\mathrm{~L}$ & Y \\
\hline Prime Bank Limited & PRIMEBANK & 1995 & $\mathrm{~L}$ & $\mathrm{Y}$ \\
\hline Pubali Bank Limited & PUBALIBANK & 1972 & $\mathrm{~L}$ & $\mathrm{Y}$ \\
\hline Shimanto Bank Limited & SHIMANTOBANK & 2016 & & $\mathrm{~N}$ \\
\hline South Bangla Agriculture \& Commerce Bank Limited & SBAC & 2013 & & $\mathrm{~N}$ \\
\hline Southeast Bank Limited & SOUTHEASTB & 1995 & $\mathrm{~L}$ & $\mathrm{Y}$ \\
\hline Standard Bank Limited & STANDBANKL & 1999 & $\mathrm{~L}$ & $\mathrm{Y}$ \\
\hline The City Bank Limited & CITYBANK & 1983 & $\mathrm{~L}$ & Y \\
\hline The Farmers Bank Limited & FBL & 2013 & & $\mathrm{~N}$ \\
\hline Trust Bank Limited & TRUSTBANK & 1999 & $\mathrm{~L}$ & $\mathrm{Y}$ \\
\hline United Commercial Bank Limited & $\mathrm{UCB}$ & 1983 & $\mathrm{~L}$ & $\mathrm{Y}$ \\
\hline Uttara Bank Limited & UTTARABANK & 1965 & $\mathrm{~L}$ & $\mathrm{Y}$ \\
\hline \multicolumn{5}{|l|}{ Private Commercial Banks - Islamic Shariah Based } \\
\hline Al-Arafah Islami Bank Limited & ALARABANK & 1995 & $\mathrm{~L}$ & $\mathrm{Y}$ \\
\hline EXIM Bank Limited & EXIMBANK & 1999 & $\mathrm{~L}$ & Y \\
\hline First Security Islami Bank Limited & FIRSTSBANK & 1999 & $\mathrm{~L}$ & Y \\
\hline ICB Islamic Bank Limited & ICBIBANK & 1987 & $\mathrm{~L}$ & $\mathrm{Y}$ \\
\hline Islami Bank Bangladesh Limited & ISLAMIBANK & 1983 & $\mathrm{~L}$ & $\mathrm{Y}$ \\
\hline Shahjalal Bank Limited & SHAHJABANK & 2001 & $\mathrm{~L}$ & $\mathrm{Y}$ \\
\hline Social Islami Bank Limited & SIBL & 1995 & $\mathrm{~L}$ & $\mathrm{Y}$ \\
\hline Union Bank Limited & UNIONBANK & 2013 & & $\mathrm{~N}$ \\
\hline \multicolumn{5}{|l|}{ State Owned Commercial Banks } \\
\hline Agrani Bank Limited & AGRBANK & 1972 & & $\mathrm{Y}$ \\
\hline Bangladesh Development Bank Limited & BDBL & 2009 & & $\mathrm{Y}$ \\
\hline BASIC Bank Limited & BASIC & 1988 & & $\mathrm{Y}$ \\
\hline Janata Bank Limited & JANATA & 1971 & & $\mathrm{Y}$ \\
\hline Rupali Bank Limited & RUPALIBANK & 1986 & $\mathrm{~L}$ & $\mathrm{Y}$ \\
\hline Sonali Bank Limited & SONALIBANK & 1972 & & $\mathrm{Y}$ \\
\hline \multicolumn{5}{|l|}{ Specialized Commercial Banks } \\
\hline Bangladesh Krishi Bank & BKB & 1973 & & $\mathrm{~N}$ \\
\hline Rajshahi Krishi Unnayan Bank & RKUB & 1987 & & $\mathrm{~N}$ \\
\hline \multicolumn{5}{|l|}{ Foreign Commercial Banks } \\
\hline Bank Al-Falah Limited & AL-FALAH & 1997 & & $\mathrm{~N}$ \\
\hline Citibank N. A & CITI & 1812 & & $\mathrm{~N}$ \\
\hline Commercial Bank of Ceylon Limited & CEYLON & 1920 & & $\mathrm{~N}$ \\
\hline Habib Bank Limited & HABIBBANK & 1947 & & $\mathrm{~N}$ \\
\hline National Bank of Pakistan & NATIBANKPAK & 1949 & & $\mathrm{~N}$ \\
\hline Standard Chartered Bank & $\mathrm{SCB}$ & 1948 & & $\mathrm{~N}$ \\
\hline State Bank of India & STATEBANK & 1806 & & $\mathrm{~N}$ \\
\hline The Hong Kong and Shanghai Banking Corporation Limited & HSBC & 1836 & & $\mathrm{~N}$ \\
\hline Woori Bank & WOORIBANK & 1899 & & $\mathrm{~N}$ \\
\hline
\end{tabular}

Note: 1. ' $L$ ' indicates the bank is Listed in the Dhaka Stock Exchange Limited (DSE)

2. ' $\mathrm{Y}$ ' indicates the marked bank is included in my calculation, which is due to the availability of required data

3. ' $\mathrm{N}$ ' indicates the marked bank is not included in my calculation, which is due to the un- availability of required data

Source: Bangladesh Bank (Central Bank of Bangladesh) [17]; Dhaka Stock Exchange Limited [24]

Table A2. Related Accounting Ratios.

\begin{tabular}{|c|c|c|c|c|}
\hline \multirow[t]{3}{*}{1.} & Operating Asset Ratios & i. & Interest Margin to Assets & IMA \\
\hline & & ii. & Operating Cost to Assets & OCA \\
\hline & & iii. & Pre-Tax Profit to Assets & PA \\
\hline \multirow[t]{3}{*}{2.} & Operating Income Ratios & i. & Interest Margin to Income & IMI \\
\hline & & ii. & Operating Cost to Income & OCI \\
\hline & & iii. & Pre-Tax Profit to Income & PI \\
\hline \multirow[t]{3}{*}{3.} & Operating Equity Ratios & i. & Interest Margin to Equity & IME \\
\hline & & ii. & Operating Cost to Equity & OCE \\
\hline & & iii. & Pre-Tax Profit to Equity & PE \\
\hline
\end{tabular}

Note: 1 . Interest Margin $=$ Net Interest Income $=$ Interest Income/Profit on Investments - Interest Paid/Profit on Deposits and Borrowings

2. Income refers to Gross Income $=$ Total Operating Income

3. Assets $=$ Total Assets

4. Equity $=$ Total Shareholders' Equity 
Table A3. Used Variables in the Computation for Cost and Profit Functions.

\begin{tabular}{lll}
\hline Dependent Variables & Total Cost & \\
TC & Profit & $\begin{array}{l}\text { Operating (Personnel + Overheads) + Interest Expenses } \\
\text { Pre-Tax Profit/Profit before Taxation }\end{array}$ \\
$\pi$ & & \\
Independent Variables & Total Earning Asset & Loans, Investment and Other Earning Assets \\
$\mathrm{Q}$ & Price of Labor and Capital & Personnel and Other Overhead Expenses divided by the Total Assets \\
$\mathrm{X}_{1}$ & Price of Deposits & Income Paid to Depositors divided by Total Deposits \\
$\mathrm{X}_{2}$ &
\end{tabular}

Table A4. Descriptive Statistics of Variables (Input and Output), 2011-2015 (in BDT Million).

\begin{tabular}{|c|c|c|c|c|c|c|}
\hline Variable & $\mathbf{N}$ & Mean & Median & Minimum & Maximum & Std. Dev. \\
\hline \multicolumn{7}{|c|}{ Private Commercial Banks - Conventional } \\
\hline $\mathrm{TC}$ & 110 & $13,967.09$ & $13,148.71$ & $6,323.04$ & $48,098.72$ & $5,344.62$ \\
\hline$\pi$ & 110 & $3,325.30$ & $3,005.78$ & 470.36 & $9,391.94$ & $1,685.24$ \\
\hline $\mathrm{X}_{1}$ & 110 & $19,841.52$ & $19,204.24$ & $9,717.89$ & $32,365.64$ & $5,185.84$ \\
\hline $\mathrm{X}_{2}$ & 110 & $77,682.51$ & $79,452.56$ & $8,694.79$ & $103,377.41$ & $15,623.17$ \\
\hline \multicolumn{7}{|c|}{ Private Commercial Banks - Islamic Shariah Based } \\
\hline$\pi$ & 30 & $4,047.86$ & $3,391.29$ & 775.99 & $11,910.65$ & $3,136.01$ \\
\hline Q & 35 & $200,217.07$ & $153,737.47$ & $12,752.90$ & $725,821.12$ & $168,192.27$ \\
\hline $\mathrm{X}_{1}$ & 35 & $16,861.21$ & $15,722.42$ & $2,435.90$ & $34,938.78$ & $6,714.66$ \\
\hline $\mathrm{X}_{2}$ & 35 & $100,427.86$ & $75,783.57$ & $26,785.83$ & $1,097,551.40$ & $174,799.82$ \\
\hline \multicolumn{7}{|c|}{ State Owned Commercial Banks } \\
\hline $\mathrm{TC}$ & 30 & $24,371.82$ & $20,748.85$ & $1,049.09$ & $60,750.79$ & $17,420.58$ \\
\hline$\pi$ & 23 & $3,526.88$ & $1,704.85$ & 118.49 & $10,625.32$ & $3,338.62$ \\
\hline Q & 30 & $378,862.00$ & $324,685.23$ & $28,847.66$ & $1,026,108.51$ & $291,505.33$ \\
\hline $\mathrm{X}_{2}$ & 30 & $66,701.50$ & $66,495.60$ & $42,015.60$ & $97,461.66$ & $15,172.78$ \\
\hline \multicolumn{7}{|c|}{ All Commercial Banks of Bangladesh } \\
\hline $\mathrm{TC}$ & 175 & $15,977.45$ & $13,328.98$ & 874.22 & $60,750.79$ & $10,380.18$ \\
\hline$\pi$ & 163 & $3,486.73$ & $3,004.17$ & 118.49 & $11,910.65$ & $2,293.76$ \\
\hline Q & 175 & $206,067.06$ & $157,153.71$ & $12,752.90$ & $1,026,108.51$ & $167,539.06$ \\
\hline $\mathrm{X}_{1}$ & 175 & $18,594.30$ & $17,560.24$ & $2,435.90$ & $34,938.78$ & $5,494.98$ \\
\hline $\mathrm{X}_{2}$ & 175 & $80,349.12$ & $77,299.94$ & $8,694.79$ & $1,097,551.40$ & $79,243.22$ \\
\hline
\end{tabular}

Note: $\mathrm{TC}=$ Total Costs; $\pi=$ Profits; $\mathrm{Q}=$ Total Earning Assets, $\mathrm{X}_{1}=$ Price of Labor and Capital; $\mathrm{X}_{2}=$ Price of Deposits

Source: Own computation; Data taken from the Annual Reports of respective banks from 2011 to 2015

Table A5. Operating Ratios (Mean Values of 2011-2015 in percentage (\%)).

\begin{tabular}{|c|c|c|c|c|c|c|c|c|c|}
\hline & \multicolumn{3}{|c|}{ Operating Asset Ratios } & \multicolumn{3}{|c|}{ Operating Income Ratios } & \multicolumn{3}{|c|}{ Operating Equity Ratios } \\
\hline & IMA & OCA & PA & IMI & OCI & PI & IME & OCE & PE \\
\hline \multicolumn{10}{|c|}{ Private Commercial Banks - Conventional } \\
\hline ABBANK & 1.83 & 2.17 & 1.96 & 39.38 & 46.85 & 42.15 & 21.63 & 25.33 & 23.06 \\
\hline BANKASIA & 1.97 & 2.02 & 2.23 & 42.16 & 45.52 & 49.51 & 21.01 & 21.76 & 23.84 \\
\hline BRACBANK & 3.86 & 3.50 & 1.85 & 56.28 & 50.83 & 26.76 & 53.52 & 48.63 & 25.00 \\
\hline DHAKABANK & 1.88 & 1.81 & 2.01 & 41.93 & 41.10 & 43.10 & 23.52 & 22.74 & 24.63 \\
\hline DUTCHBANG & 4.10 & 3.93 & 2.69 & 59.40 & 57.17 & 38.69 & 58.71 & 56.43 & 38.37 \\
\hline IFIC & 2.18 & 2.76 & 1.58 & 42.58 & 53.81 & 30.44 & 31.92 & 40.39 & 22.91 \\
\hline JAMUNABANK & 1.34 & 2.21 & 1.91 & 27.05 & 45.27 & 38.47 & 16.20 & 26.48 & 23.13 \\
\hline MERCANBANK & 1.33 & 2.09 & 1.83 & 28.66 & 44.95 & 38.87 & 16.46 & 25.74 & 22.51 \\
\hline MTB & 1.07 & 2.36 & 1.11 & 25.79 & 58.04 & 26.65 & 18.17 & 40.81 & 18.61 \\
\hline NBL & 1.91 & 2.60 & 2.58 & 33.39 & 48.86 & 44.52 & 16.83 & 23.64 & 22.16 \\
\hline NCCBANK & 1.96 & 1.91 & 1.79 & 58.48 & 55.94 & 56.88 & 18.66 & 18.15 & 17.08 \\
\hline ONEBANKLTD & 3.02 & 2.63 & 2.74 & 53.65 & 46.76 & 47.48 & 35.76 & 31.10 & 31.93 \\
\hline PRIMEBANK & 1.55 & 2.22 & 1.89 & 28.74 & 42.79 & 34.99 & 33.21 & 41.19 & 34.81 \\
\hline PUBALIBANK & 2.93 & 2.48 & 2.53 & 52.09 & 44.68 & 45.31 & 30.40 & 26.14 & 26.39 \\
\hline SOUTHEASTB & 1.18 & 1.32 & 2.47 & 25.77 & 29.01 & 53.88 & 11.02 & 12.41 & 23.17 \\
\hline STANDBANKL & 2.34 & 1.67 & 2.23 & 51.35 & 37.04 & 48.76 & 27.02 & 19.35 & 25.51 \\
\hline CITYBANK & 3.27 & 3.05 & 1.94 & 52.16 & 49.00 & 30.98 & 24.43 & 23.03 & 14.43 \\
\hline TRUSTBANK & 1.50 & 1.93 & 1.38 & 39.74 & 52.51 & 35.93 & 25.23 & 31.75 & 23.02 \\
\hline UCB & 2.99 & 2.26 & 2.50 & 55.86 & 42.05 & 46.29 & 33.72 & 25.52 & 28.08 \\
\hline UTTARABANK & 1.61 & 8.37 & 2.17 & 26.68 & 147.03 & 36.79 & 18.27 & 97.18 & 25.03 \\
\hline MEAN & 2.14 & 2.68 & 2.06 & 41.49 & 53.04 & 40.76 & 25.87 & 32.62 & 24.17 \\
\hline
\end{tabular}




\begin{tabular}{|c|c|c|c|c|c|c|c|c|c|}
\hline & \multicolumn{3}{|c|}{ Operating Asset Ratios } & \multicolumn{3}{|c|}{ Operating Income Ratios } & \multicolumn{3}{|c|}{ Operating Equity Ratios } \\
\hline & IMA & OCA & PA & IMI & OCI & PI & IME & OCE & PE \\
\hline \multicolumn{10}{|c|}{ Private Commercial Banks - Islamic Shariah Based } \\
\hline ALARABANK & 3.07 & 1.48 & 2.31 & 70.86 & 34.39 & 52.74 & 36.59 & 17.73 & 27.23 \\
\hline EXIMBANK & 2.89 & 1.75 & 1.97 & 64.47 & 38.99 & 43.42 & 28.32 & 17.08 & 19.17 \\
\hline FIRSTSBANK & 2.21 & 1.40 & 0.95 & 81.74 & 52.14 & 34.49 & 52.44 & 33.47 & 22.10 \\
\hline ICBIBANK & 1.45 & 3.19 & (3.17) & 63.51 & 143.21 & $(159.17)$ & $(3.51)$ & $(6.14)$ & 9.48 \\
\hline ISLAMIBANK & 3.16 & 1.88 & 1.99 & 69.46 & 41.77 & 43.08 & 42.74 & 25.54 & 26.76 \\
\hline SHAHJABANK & 2.64 & 1.79 & 1.75 & 63.28 & 43.63 & 40.97 & 32.11 & 21.29 & 21.91 \\
\hline SIBL & 3.17 & 1.80 & 2.06 & 69.26 & 39.32 & 44.79 & 37.31 & 21.08 & 23.91 \\
\hline MEAN & 2.65 & 1.90 & 1.12 & 68.94 & 56.21 & 14.33 & 32.29 & 18.58 & 21.51 \\
\hline MEAN (without ICBIBANK) & 2.86 & 1.68 & 1.84 & 69.85 & 41.71 & 43.25 & 38.25 & 22.70 & 23.51 \\
\hline \multicolumn{10}{|l|}{ State-Owned Commercial Banks } \\
\hline AGRBANK & 0.94 & 1.83 & $(0.21)$ & 19.41 & 45.97 & $(12.30)$ & 20.81 & 38.27 & (41.93) \\
\hline BDBL & 1.81 & 2.32 & 2.61 & 31.49 & 42.26 & 46.26 & 4.18 & 5.75 & 6.41 \\
\hline BASIC & 0.74 & 1.76 & 0.27 & (391.13) & 413.45 & $(407.87)$ & 16.71 & 28.06 & 6.85 \\
\hline JANATA & 0.55 & 1.55 & 0.64 & 10.17 & 41.06 & 17.96 & 11.68 & 28.15 & 2.95 \\
\hline RUPALIBANK & 0.81 & 1.79 & 0.72 & 15.34 & 57.39 & 19.96 & 7.91 & 28.75 & 10.01 \\
\hline SONALIBANK & $(0.73)$ & 1.45 & $(0.50)$ & $(37.21)$ & 59.99 & $(15.85)$ & $(13.88)$ & 28.00 & $(25.41)$ \\
\hline MEAN & 0.69 & 1.78 & 0.59 & $(58.66)$ & 110.02 & $(58.64)$ & 7.90 & 26.16 & $(6.85)$ \\
\hline MEAN (without BASIC) & 0.68 & 1.79 & 0.65 & 7.84 & 49.33 & 11.21 & 6.14 & 25.78 & $(9.59)$ \\
\hline
\end{tabular}

Source: Own computation; Data taken from the Annual Reports of respective banks from 2011 to 2015

Table A6. Cost Efficiency Scores, (2011-2015).

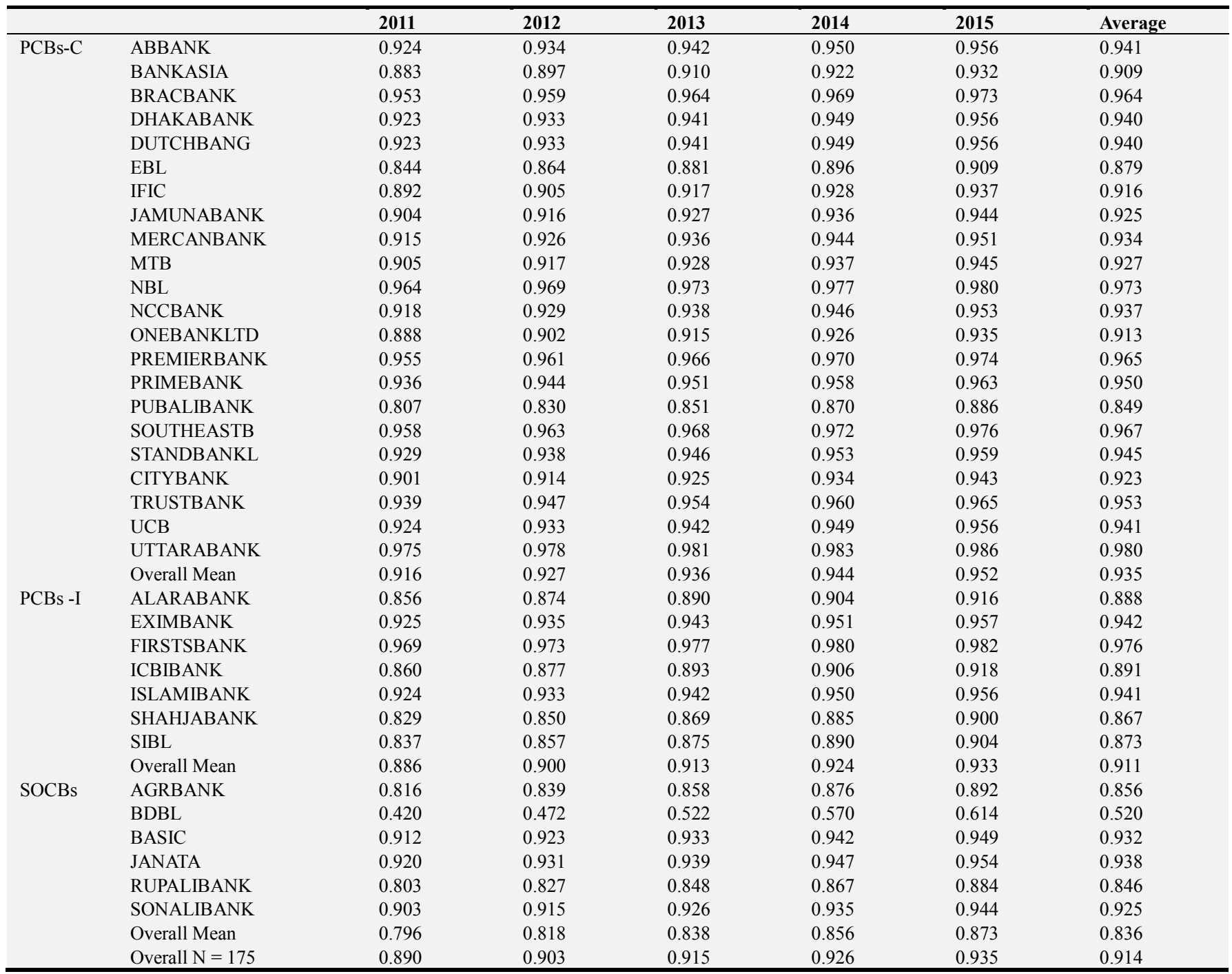

Source: Own computation using Frontier 4.1 developed by Coelly (1995);

Data taken from the Annual Reports of respective banks from 2011 to 2015 
Table A7. Profit Efficiency Scores, (2011-2015).

\begin{tabular}{|c|c|c|c|c|c|c|c|}
\hline & & 2011 & 2012 & 2013 & 2014 & 2015 & Average \\
\hline \multirow[t]{23}{*}{ PCBs-C } & ABBANK & 0.891 & 0.871 & 0.847 & 0.820 & 0.789 & 0.843 \\
\hline & BANKASIA & 0.916 & 0.900 & 0.882 & 0.860 & 0.835 & 0.879 \\
\hline & BRACBANK & 0.884 & 0.862 & 0.837 & 0.808 & 0.775 & 0.833 \\
\hline & DHAKABANK & 0.845 & 0.818 & 0.785 & 0.749 & 0.707 & 0.781 \\
\hline & DUTCHBANG & 0.880 & 0.858 & 0.832 & 0.803 & 0.769 & 0.828 \\
\hline & EBL & 0.944 & 0.933 & 0.920 & 0.905 & 0.887 & 0.918 \\
\hline & IFIC & 0.748 & 0.705 & 0.657 & 0.604 & 0.547 & 0.652 \\
\hline & JAMUNABANK & 0.854 & 0.828 & 0.797 & 0.762 & 0.723 & 0.793 \\
\hline & MERCANBANK & 0.849 & 0.821 & 0.790 & 0.754 & 0.713 & 0.785 \\
\hline & МТB & 0.645 & 0.590 & 0.530 & 0.466 & 0.400 & 0.526 \\
\hline & NBL & 0.923 & 0.908 & 0.891 & 0.871 & 0.848 & 0.888 \\
\hline & NCCBANK & 0.725 & 0.680 & 0.629 & 0.573 & 0.513 & 0.624 \\
\hline & ONEBANKLTD & 0.938 & 0.926 & 0.912 & 0.895 & 0.876 & 0.910 \\
\hline & PREMIERBANK & 0.740 & 0.696 & 0.647 & 0.593 & 0.534 & 0.642 \\
\hline & PRIMEBANK & 0.790 & 0.754 & 0.712 & 0.666 & 0.614 & 0.707 \\
\hline & PUBALIBANK & 0.932 & 0.919 & 0.904 & 0.886 & 0.865 & 0.901 \\
\hline & SOUTHEASTB & 0.933 & 0.920 & 0.904 & 0.887 & 0.866 & 0.902 \\
\hline & STANDBANKL & 0.886 & 0.865 & 0.840 & 0.812 & 0.779 & 0.836 \\
\hline & CITYBANK & 0.881 & 0.859 & 0.833 & 0.804 & 0.770 & 0.830 \\
\hline & TRUSTBANK & 0.705 & 0.657 & 0.603 & 0.545 & 0.483 & 0.598 \\
\hline & $\mathrm{UCB}$ & 0.945 & 0.934 & 0.922 & 0.907 & 0.890 & 0.920 \\
\hline & UTTARABANK & 0.870 & 0.847 & 0.819 & 0.787 & 0.751 & 0.815 \\
\hline & Overall Mean & 0.851 & 0.825 & 0.795 & 0.762 & 0.724 & 0.791 \\
\hline \multirow[t]{8}{*}{ PCBs -I } & ALARABANK & 0.909 & 0.892 & 0.872 & 0.849 & 0.822 & 0.869 \\
\hline & EXIMBANK & 0.864 & 0.839 & 0.810 & 0.777 & 0.739 & 0.806 \\
\hline & FIRSTSBANK & 0.519 & 0.455 & 0.387 & 0.319 & 0.253 & 0.387 \\
\hline & ICBIBANK & N/A & N/A & N/A & N/A & N/A & \\
\hline & ISLAMIBANK & 0.914 & 0.898 & 0.879 & 0.857 & 0.831 & 0.876 \\
\hline & SHAHJABANK & 0.717 & 0.671 & 0.619 & 0.562 & 0.501 & 0.614 \\
\hline & SIBL & 0.883 & 0.861 & 0.836 & 0.807 & 0.774 & 0.832 \\
\hline & Overall Mean & 0.801 & 0.769 & 0.734 & 0.695 & 0.654 & 0.731 \\
\hline \multirow[t]{8}{*}{ SOCBs } & AGRBANK & & N/A & & & N/A & \\
\hline & BDBL & 0.830 & 0.800 & 0.765 & 0.725 & 0.681 & 0.760 \\
\hline & BASIC & & & & N/A & N/A & \\
\hline & JANATA & & N/A & & & & \\
\hline & RUPALIBANK & 0.406 & 0.337 & 0.270 & 0.207 & 0.150 & 0.274 \\
\hline & SONALIBANK & & N/A & & & N/A & \\
\hline & Overall Mean & 0.618 & 0.569 & 0.518 & 0.466 & 0.416 & 0.517 \\
\hline & Overall $\mathrm{N}=150$ & 0.826 & 0.797 & 0.764 & 0.729 & 0.689 & 0.761 \\
\hline
\end{tabular}

Source: Own computation using Frontier 4.1 developed by Coelly (1995);

Data taken from the Annual Reports of respective banks from 2011 to 2015

Table A8. Maximum Likelihood Parameter Estimates of Cost Function.

\begin{tabular}{|c|c|c|c|}
\hline \multicolumn{4}{|c|}{ Dependent Variable: In(TC) } \\
\hline Parameter & Variable & Coefficient & Standard Error \\
\hline$\beta_{0}$ & Constant & $(0.103)$ & 0.997 \\
\hline$\beta_{1}$ & Total Earning Asset (TEA) & 0.505 & 0.788 \\
\hline$\beta_{2}$ & Price of Labor and Capital (PLC) & 0.141 & 0.952 \\
\hline$\beta_{3}$ & Price of Deposits (PD) & 0.125 & 0.118 \\
\hline$\beta_{4}$ & $\left(\right.$ Total Earning Asset) ${ }^{2}$ & $(0.765)$ & 0.236 \\
\hline$\beta_{5}$ & (Price of Labor and Capital) $^{2}$ & $(0.569)$ & 0.702 \\
\hline$\beta_{6}$ & $(\text { Price of Deposits) })^{2}$ & 0.900 & 0.194 \\
\hline$\beta_{7}$ & TEA X PLC & $(0.174)$ & 0.680 \\
\hline$\beta_{8}$ & TEA X PD & $(0.562)$ & 0.655 \\
\hline$\beta_{9}$ & PLC X PD & $(0.643)$ & 0.100 \\
\hline Sigma-square & $\sigma^{2}=\sigma_{v}^{2}+\sigma_{u}^{2}$ & 0.632 & 0.147 \\
\hline Gamma & $\gamma=\sigma_{\mathrm{u}}^{2} /\left(\sigma_{\mathrm{v}}^{2}+\sigma_{\mathrm{u}}^{2}\right)$ & 0.638 & 0.936 \\
\hline $\mathrm{Mu}$ & & $(0.401)$ & 0.182 \\
\hline Eta & & 0.145 & 0.588 \\
\hline Log Likelihood Function & & 0.641 & \\
\hline
\end{tabular}

Note: $\mathrm{N}=175$ 
Table A9. Maximum Likelihood Parameter Estimates of Profit Function.

\begin{tabular}{|c|c|c|c|}
\hline \multicolumn{4}{|l|}{ Dependent Variable: $\ln (\pi)$} \\
\hline Parameter & Variable & Coefficient & Standard Error \\
\hline$\beta_{0}$ & Constant & 0.151 & 0.680 \\
\hline$\beta_{1}$ & Total Earning Asset (TEA) & $(0.134)$ & 0.474 \\
\hline$\beta_{2}$ & Price of Labor and Capital (PLC) & 0.131 & 0.684 \\
\hline$\beta_{3}$ & Price of Deposits (PD) & 0.104 & 0.378 \\
\hline$\beta_{4}$ & ${\text { (Total Earning Asset })^{2}}^{2}$ & 0.127 & 0.892 \\
\hline$\beta_{5}$ & $(\text { Price of Labor and Capital) })^{2}$ & $(0.172)$ & 0.400 \\
\hline$\beta_{7}$ & TEA X PLC & 0.257 & 0.277 \\
\hline$\beta_{8}$ & TEA X PD & 0.779 & 0.254 \\
\hline$\beta_{9}$ & PLC X PD & $(0.115)$ & 0.324 \\
\hline Sigma-square & $\sigma^{2}=\sigma_{\mathrm{v}}^{2}+\sigma_{\mathrm{u}}^{2}$ & 0.153 & 0.746 \\
\hline Gamma & $\gamma=\sigma_{u}^{2} /\left(\sigma_{v}^{2}+\sigma_{u}^{2}\right)$ & 0.933 & 0.375 \\
\hline $\mathrm{Mu}$ & & $(0.239)$ & 0.181 \\
\hline Eta & & $(0.187)$ & 0.543 \\
\hline
\end{tabular}

Note: $\mathrm{N}=150$

\section{References}

[1] Ikhide, S. (2000), "Efficiency of Commercial Banks in Namibia", BON Occasional Paper No. 4. Bank of Namibia, Research Department.

[2] Irsova, Z. B. (2009), "Measuring Bank Efficiency", Master Thesis, Charles University in Prague, Czechia.

[3] Farrell, M. J. (1957), "The Measurement of Productive Efficiency", Journal of Royal Statistical Society A 120, Part 3 , 253-281.

[4] Smirlock, M. (1985), "Evidence on the (Non) Relationship between Concentration and Profitability in Banking", Journal of Money, Credit and Banking, 17, 69-83.

[5] Evanoff, D. D. \& Fortier, D. L. (1988), "Re-evaluation of the Structure-Conduct-Performance Paradigm in Banking, Journal of Financial Services Research", 1, 277-294.

[6] Rhoades, S. A. (1986), "The Operating Performance of Acquired Firms in Banking before and after Acquisition", Staff Study No. 149, Federal Reserve Board.

[7] Srinivasan, A. \& Wall, L. D. (1992), "Cost Savings Associated with Bank Mergers", Working Paper No. 92-2, Federal Reserve Bank of Atlanta, 32, 1251-1266.

[8] Cornett, M. M. \& Tehranian, H. (1992), "Changes in Corporate Performance Associated with Bank Acquisition", Journal of Financial Economics, 31, 211-234.

[9] Berger, A. N., Hunter, W. C. \& Timme, S. G. (1993), "The Efficiency of Financial Institutions: A Review and Preview of Past, Present, and Future", Journal of Banking and Finance, 17, 221-249.

[10] Aigner, D., Lovell, C. A. K. \& Schmidt, P. (1977), "Formulation and Estimation of Stochastic Frontier Production Function Models", Journal of Econometrics, 6, 21-37.

[11] Meesun, W. \& Broeck, J. V. D. (1977), "Efficiency Estimation from Cobb-Douglas Production Functions with Composed Error", International Economic Review, 18 (2), 435-444.

[12] Ferrier, G. D., \& Lovell, C. K. (1990), "Measuring Cost Efficiency in Banking: Econometrics and Linear Programming
Evidence", Journal of Econometrics, 46, 229-245.

[13] Okuda, H., Hashimoto, H. \& Murakami, M. (2003), "The Estimation of Stochastic Cost Functions of Malaysian Commercial Banks and Its Policy Implications to Bank Restructuring", Centre for Economic Institutions, Working Paper Series No. 2003-2.

[14] Yildirim, H. S. \& Philippatos, G. C. (2007), "Efficiency of Banks: Recent Evidence from the Transition Economies of Europe, 19932000", The European Journal of Finance, 13 (2), 123-143.

[15] Aigner, D. J. \& S. F. Chau (1968), “On Estimating Industry Production Function", American Economic Review, 58, 826839.

[16] Battese, G. E. \& Coelli, T. J. (1988), "Prediction of Firm Level Technical Efficiencies with a Generalized Frontier Production Function and Panel Data", Journal of Econometrics, 38, 387-399.

[17] Bangladesh Bank, at www.bangladeshbank.org/fnansys/bankfi, April 01, 2017.

[18] Bangladesh Bank (The Central Bank of Bangladesh), "Banking Sector Performance, Regulation and Bank Supervision”, Annual Report: July 2015-June 2016, 05, 28-29.

[19] Battese, G. E. \& Coeli, T. J. (1995), “A Model for Technical Inefficiency Effects in a Stochastic Frontier Production Function for Panel Data", Empirical Economics, 20, 325-333.

[20] De Young, R. (1997), "Measuring Bank Cost Efficiency: Don't Count on Accounting Ratios", Financial Practice and Education, 20-31.

[21] Samad, A. (2009), "Measurement of Inefficiencies in Bangladesh Banking Industry using Stochastic Frontier Production Function", Global Journal of Business Research, 3 (1), 41- 48.

[22] FIS (2016), "Five Proven Approaches to Improving Bank Efficiency", at www.fisglobal.com, April 20, 2017.

[23] Dhaka Stock Exchange, at www.dsebd.org/companylistbyindustry.php?industryno $=11$, April 01, 2017.

[24] Richmond, J. (1974), "Estimating the Efficiency of Production", International Economic Review, 15 (2), 515-521. 